\title{
Introduction: The Extreme Mainstream
}

\author{
David Wittenberg
}

In her 1999 book Popular Culture: An Introduction, Carla Freccero describes what she believes will happen to academia if popular culture continues to be "a degraded cultural form in the minds of liberal educators and students":

[L]iberal arts education will will itself into anachronism - as it is already accused of doing - by focusing exclusively on forms of cultural production that are not widely shared in public culture. The domain of popular representation will pass as fact, unavailable for argument, debate, and analysis, or it will become an arena of technocratic competence where the focus will be on how to manipulate or manage it, but not analyze and interpret it. (4-5)

The theoretical quandary implicit in the somewhat apocalyptic fear Freccero voices is very familiar to academic critics of culture; quite possibly it is built into the institutional condition of academic cultural studies itself. In order to analyze what Freccero calls the most central, the most "widely shared" culture, the critic must devote her attention to precisely those cultural objects whose "technocratically competent" producers have already demonstrated a prolific and disheartening ability to "manipulate and manage" representations so as to make them "pass as fact." Confronted with such extremely mainstream texts, the critic's usual tools are even less likely than usual to be effective because, by definition, the mainstream center is occupied by objects and images that have already proved wholly consumable by the culture at large and are therefore, de facto, no longer much distressed by "argument, debate, and analysis." In short, the most extreme mainstream culture is, virtually by definition, simultaneously the most representative of "the popular" 
itself and the least vulnerable to attack by academic theory and criticism.

Under such circumstances, what I have identified as the "apocalyptic" tone of Freccero's statements starts to look less like a prediction and more like a rhetorical flourish, tethered by mere convention to an older language of the philosophical sublime. In the face of the extreme administration of the popular mainstream, such a tone may be, at best, an anachronistic residue from the old days of the literary scholar (more confident in the reach of his powers) or, at worst, a symptom of the irrelevance of academic cultural theory itself. How, then, do we read the import of Freccero's prophesy, the threat to which she gives voice? How ought we to deal with the fact that, for the most part, neither the producer nor the consumer of mainstream culture will feel the same "threat" we feel? Indeed, is the very notion of mainstream culture as something threatening a sign of the increasingly vast gulf between the cultural critic's intentions and those of the aforementioned producers and consumers, whose way in the world (so to speak) is most consummately nonthreatening? And what kind of a counter-threat is the cultural critic or theorist really able to impose?

Reclaiming, both guardedly and gleefully, the much overused term "extreme," we have entitled this issue "The Extreme Mainstream" in order to convey a double sense of what might still be considered "extreme" about mainstream culture for the academic critic of culture. First, each of the authors in this issue is interested, to some degree, in cultural objects and practices that already "pass as fact" within the cultural center and that may therefore escape academic critical attention precisely because, in their extreme visibility, they appear to be forgone conclusions. The notion of the extremely mainstream, despite its etymological ironies, is not oxymoronic, but rather expresses the more fundamental irony that what is most mainstream within popular culture is at once nearest to, and farthest from, the sphere of influence of the critic. Second, due to the ironic "extremity" of the mainstream for academic criticism, each of these authors is also, by necessity, concerned with the extremity into which that very culture thrusts him- or herself as an academic cultural critic. Cultural studies, even prior to its vital prehistory in the Frankfurt School and in other forms of "late Marxism," has always understood that an effective critique of mainstream culture must also contain a meta-critique of the fraught dialectical relationship between "the popular" and criticism itself. No academic critic of popular culture can fail to confront, either implicitly or explicitly, the quandary that the basic terms "mainstream" and "critical" (or, for that matter, "mainstream" and "academic") emerge, within late capitalist culture, from distinct, usually competing, possibly incommensurable businesses and institutions. In this sense, all criticism of the mainstream tends toward the radical, the extreme, whether self-consciously, in its acknowledgment of the extremity of the social and political alienation out of which it is compelled to speak, or unselfconsciously, in the tragicomic failure of its critical, intellectual, or even apocalyptic language to correspond to the representations it attacks. All this is to reiterate what any academic critic of popular culture already knows, at least at those moments when he or she has the leisure for self-scrutiny: criticism always entails a double task: to parley with the popular object itself and to renegotiate the critic's own extremity in relation to that 
object. And because of the doubleness of the critic's task, in the face of the extreme single-mindedness of mainstream culture, the critical viewpoint suffers from - or exults in - a virtually predetermined relegation to the fringe. For this reason, critics of popular culture have often preferred the fringe itself, even the relative fringe of the mainstream center-Alien, Twin Peaks, and Madonna, say, rather than The Return of the King, American Idol, and Outkast.

Fabio Akcelrud Durão's “A Short Circuit of Reading: Red Dragon as AntiTheory" confronts head-on the critic's difficulty with the peculiarly flat and conventional character of the mainstream object. He asks, "how can one interpret something that is just like countless examples of its genre ... without transforming contingency into necessity, chance into purpose?" For Durão, the film Red Dragon, a typical yet illuminating revision of the detective genre, is about writing, about image-making, about acts of interpretation - and then again, it is about the specter of aggression or antagonism that haunts the relationship between critic and text, just as it does the relationship between detective and criminal. Yet the critic's simple discovery of the film's being "about" these things is not yet sufficient material for a "reading," which must also address the film's resistance to critical interpretation as such, the curiously frustrating accessibility of the film's "decoded" message. Hence a "short circuit" is required, a critical strategy that interprets its own tendency toward "neutralization" - not an easy strategy, to be sure, but a necessary one, lest the film's pervasive allegorical message that "reading is evil" become literalized.

Vivian Nun Halloran's “Biting Reality: Extreme Eating and the Fascination with the Gustatory Abject" also takes an antithetical approach to the critique of the mainstream, in this case looking at spectacles of "extreme eating," which she identifies as manifestations of the "gustatory abject." Invoking Julia Kristeva's complex analysis of spectacles of horror, Halloran analyzes the "jouissance," the "simultaneous pleasure and revulsion," of spectacular gustatory displays, such as eating contests, stunt shows like Fear Factor, and the subculture of the "eating fetish," as well as the connections between these phenomena and not-yet adequately understood socio-psychological disorders, such as bulimia and anorexia. The scope of Halloran's critical questioning is ambitious. What, she asks, do extreme mainstream spectacles of food and eating - spectacles manufactured from phenomena so utterly basic and familiar to human life, yet so peculiar and idiosyncratic in their cultural functions - tell us about how we narrate fundamental relationships between subject and object, between the "I" and the "Not-I"?

Carol Vanderveer Hamilton's "The Evil of Banality: Moby Dick vs. the Extreme Machine" attacks that ever-increasingly pervasive symbol of American extremity, the sport utility vehicle (SUV), analyzing the "possessive individualism, American exceptionalism, and [the] darker, less conscious psychological malaise" of both the popular image of the SUV and the all-too-physical presence of "extreme machines" in the cultural environment. In an effective synthesis of literary history, cultural criticism, and psychoanalytical interpretation, Hamilton maps the strange psychosocial history of "grandiosity" in the United States, from Melville's symbolization of "narcissistic rage" in Moby-Dick, through contemporary discourses of indi- 
love and failure leave behind a permanent injury to self-regard in the form of a narcissistic scar, which in my opinion contributes more than anything to the sense of inferiority so common in neurotics. ("Beyond the Pleasure Principle" 603, emphasis added)

\section{Works Cited}

Baudrillard, Jean. America. London: Verso, 1989.

Bradsher, Keith. High and Mighty: SUVs: The World's Most Dangerous Vehicles and How They Got That Way. New York: Public Affairs, 2002.

Chodorow, Nancy J. The Power of Feelings: Personal Meaning in Psychoanalysis, Gender, and Culture. New Haven, CT: Yale University Press, 2001.

Culley, Travis Hugh. The Immortal Class: Bike Messengers and the Cult of Human Power. New York: Villard Books, 2001.

Davis, Lance E., Robert E. Gallmen, and Karin Gleiter. In Pursuit of Leviathan: Technology, Institutions, Productivity, and Profits in American Whaling 1816-1906. Chicago: University of Chicago Press, 1997.

Don't Say a Word. Dir. Gary Fleder. Perf. Michael Douglas. 20th Century Fox, 2001.

Emerson, Ralph Waldo. "Nature." Essays and Lectures. New York: Library of America, 1983. 9-49.

Feidelson, Charles. Symbolism and American Literature. 1953. Chicago: University of Chicago Press, 1979.

Freud, Sigmund. "Beyond the Pleasure Principle." The Freud Reader. Ed. Peter Gay. New York: Norton, 1995. 594-626.

—. "The Future of an Illusion." The Freud Reader. Ed. Peter Gay. New York: Norton, 1995. 686-722.

Lasch, Christopher. The Culture of Narcissism: American Life in an Age of Diminishing Expectations. New York: Norton, 1979.

-. The Minimal Self: Psychic Survival in Troubled Times. New York: Norton, 1984.

Melville, Herman. Redburn, White-Jacket, Moby-Dick. New York: New American Library, 1983.

Politically Incorrect. Host Bill Maher. ABC. 22 Apr. 2001.

Reising, Russell. The Unusable Past: Theory and the Study of American Literature. New York: Methuen, 1986.

Roberts, Paul. "Bad Sports: Or How We Learned to Stop Worrying and Love the SUV." Harper's Magazine April 2001: 69-75.

Rogin, Michael Paul. Subversive Genealogy: The Politics and Art of Herman Melville. Berkeley: University of California Press, 1985.

Rosenbaum, David E. "Senate Deletes Higher Mileage Standard in Energy Bill." New York Times 14 Mar. 2002: 28.

Unfaithful. Dir. Adrian Lyne. Perf. Richard Gere and Diane Lane. 20th Century Fox, 2002. 